\title{
Interpersonal relationships potential in shaping emotional safety of university educational environment
}

\author{
Elena V. Kiseleva ${ }^{1, *}$ \\ ${ }^{1}$ NSPU, Department of Pedagogy and Psychology, 630126, Novosibirsk, Russia
}

\begin{abstract}
The paper analyzes approaches to the problem of psychologically safe educational environment and resources to achieve such safety. It looks at the potential of interpersonal relationships in shaping emotionally safe educational environment, presents the results of empirical research related to first-year students' fears and apprehensions. It discusses personal qualities that may contribute to or hamper productive interpersonal relationships. There is a structural analysis of emotionally safe and unsafe educational environments of the university.
\end{abstract}

Practically for everyone, each new spiral of life activity is associated with the growing apprehension as to the person's future and his or her condition in it. Students who have just enrolled in the first year of a college or university are not an exception. Expectations of new turns of their lives make almost all of them apprehensive and anxious, which is sometimes expressed in a constant feeling of fear. This may be proved by the results of 5year-long surveys among freshmen of Novosibirsk State Pedagogical University during their first days of undergraduate study.

Steady fears are considered by researchers as evidence of emotionally unsafe environment. There are two constituent elements of emotional safety: the level of negative emotions (as indicated by emotions of fear or anxiety) and the level of positive emotions (as indicated by the emotion of pleasure) [1].

This issue is usually raised as a part of a more general problem of safe educational environment for humans [6]. Its significance and need to take special effort in creating a comfortable pedagogical environment was described by D.I. Fel'dshteyn [2].

The emotional part of educational environment psychological safety is one of the most urgent because emotions often turn out to be causes of both behavioral reactions and cognitive attitudes [3].

Psychological safety is traditionally defined as such a condition of educational environment which 1) is free from any signs of psychological violence in interrelationships, 2) helps to satisfy individual needs in personal and trusting interaction, 3) creates reference significance of the educational environment for its participants, and 4) contributes to better mental health of everyone involved [4].

Therefore, the growth and expansion of people's noticeable fears and anxieties may also be an evidence of an emotionally (psychologically) unsafe environment.
Fear is defined as one of the primary human emotions; it gives an alarm about danger and depends on many external and internal as well as inherent or acquired factors. Here are the cognitively structured causes of fear: the feeling of loneliness, abandonment, depression, threat to self-respect, imminent failure or one's personal inadequacy. Fear leads to emotional insecurity and strong nervous tension, which, in turn, creates the desire to run away and look for protection.

The basic fear functions and accompanying emotional conditions are signaling, defensive, adaptive and searching states [5].

Anxiety ("opasenie"in Russian, from the old Russian word "opas", or caution and defense) means apprehension, the mental picture of threat; it is different from mental reflection, interpretation or understanding of tendencies [6].

According to I.A. Baeva, the emotional safety of educational environment is an integral part of the general psychological safety of the educational environment, its emotional component. The key criterion of the safe educational environment is the fact that it ensures psychological health of all its subjects and participants [4].

Emotionally unsafe educational environment causes negative emotions. Negative emotions toward the world are naturally transformed into negative self-esteem, one's abilities, opportunities and one's place in the society. Negative emotions lead to lower self-esteem, etc. So, if a person finds himself in the educational environment filled with negative emotions, he will tend to speak and think about himself in a negative light, underestimate his abilities and potential [1].

Five-year-long research results of fears and anxieties of freshmen during their first days of an undergraduate study show that about $60 \%$ of students are clearly afraid of possible future problems in relationships, primarily

* Corresponding author: elena mig@mail.ru 
with their classmates and senior students. Here is what they say:

- I am afraid I will not get along with others in the group;

- I am afraid to communicate with people who I know little;

- I am afraid to face misunderstanding in my class;

- I am afraid of future relationships with my classmates and senior students;

- I am afraid I will not find a common language with my classmates;

- I am afraid something will go wrong with my relationships in the group;

- I am afraid to offend somebody;

- I am afraid I will not make friends;

- I am afraid of aggression from my classmates;

- I am afraid of disrespect from senior students;

- I am afraid I will have to participate in everything, to socialize with everyone;

- I am afraid I will not be accepted by my classmates;

- I am anxious as I don't know how to establish myself in the group;

- I am afraid of having many new people around;

- I am afraid of loneliness and misunderstanding;

- I am anxious that I do not know my classmates well enough;

- I am afraid of my classmates' attitude to me;

- I am afraid of some division in the group;

- I feel apprehensive regarding conflicts in the group;

- I am afraid I will not find the like-minded people.

Approximately $23 \%$ of students are anxious about possible problems with the faculty:

- I am afraid to deal with the faculty;

- I am worried about my relationships with the faculty;

- I am anxious about relationships with professors;

- I am afraid I will not find a common language with professors;

- I am afraid I will not understand some professors.

$28 \%$ of students are anxious about their study, exams, etc.:

- I am afraid I will not make good progress;

- I am afraid I will fail the exams;

- I am afraid of the new way of studying;

- I am afraid of the coming exams!

- I am afraid of challenges in my study;

- I am afraid I will not be psychologically able to cope with studies;

- I am afraid I will not have enough energy for everything;

- I am afraid I will be sick and tired of History;

- I am afraid of failing the exams and being expelled;

- I am afraid I will not be able to cope with the academic program.

Some students are uneasy regarding their accommodation and everyday problems in the dormitory:

- I am afraid it will be dirty in the dorm;

- I am afraid of the life in the dorm.

$12 \%$ of students are afraid they will not meet the university requirements (they may be late for classes because of traffic jams, etc.):
- I am anxious about the proper time management;

- I am afraid I will be late;

- I am afraid I will not have enough time;

- I am afraid I will not do well academically.

Our experience of work with students shows that purposeful work towards the development of interpersonal relationships in the students' environment, teaching students to master skills and technologies of productive interpersonal relationships leads to better emotional characteristics of the educational environment, which, in turn, reduces the amount of fears and anxiety among first-year students.

T.N. Berezina believes that there are two things which will improve emotional characteristics of the educational environment.

- Firstly, we must decrease the level of negative emotions. It is highly advisable to deal with students' fears and anxieties caused by the study process and exams. This work will diminish possible psychological and physiological consequences and the risk of psychosomatic illnesses.

- Secondly, it is necessary to increase the amount and quality of positive emotions [7].

Due to the fact that it is the problem of relationships which troubles the majority of first-year students, we must probably focus on relationships as a resource which will improve emotional characteristics of the educational environment. However, to decrease the level of students' negative emotions, it is necessary to teach them about the nature of interpersonal relationships and the technologies of building the best possible interactions.

As a study material, students may be introduced to some research, e.g. Ya.L. Kolominsky's research that he took in some youth collectives and in which he identified personal qualities that made the subject more attractive in socializing and interpersonal relationships as well as qualities reducing the appeal of an individual in interpersonal relationships.

Among the qualities that make people more attractive in socializing and interpersonal relationships, the author includes the following: friendliness, sociability, readiness to help, loyalty in friendship, good abilities, outward appearance (or neatness), sense of humor (or cheerfulness), independence, initiative, rich imagination, and ability to keep secrets.

Qualities reducing the appeal of an individual in interpersonal relationships are seen by the author as rudeness, reticence, reserved character, greed, laziness, falsity, envy, untidiness, bad habits, sloppy manners, and lack of abilities [8, p. 168].

As for technologies of building the best possible interactions, they may include the "interactions wave" technology that we mentioned earlier [9].

Making students aware of the most productive communicative strategies also brings a good effect in building interpersonal relationships [10].

Apart from that, our experience of social education in a pedagogical university shows that if educational environment is filled with creative and intellectually encouraging events, we may observe accelerated formation of favorable emotional relationships in the student-teacher environment while student gains a whole 
set of positive emotions which, in their turn, improve emotional safety of educational environment.

Effective interpersonal relationships shaped within students' university life help them to accumulate positive experience of solving personal and interpersonal problems which, in turn, boosts their self-confidence and develops the overall positive attitude in interpersonal communication. Positive emotions give birth to cooperation in interaction, the feeling of "belonging to the common fate" and develop emotionally safe educational environment.

This publication was possible due to the Russian Humanitarian Science Foundation grant, Project № 15-06$10447 \mathrm{a}$.

\section{References}

1. S. Rubtsov, and T.N Berezina, Psihologicheskaya nauka i obrazovanie, 6, 101 (2013) [In Rus]

2. D.I. Fel'dshteyn, Mir psihologii , 1, 204 (2012) [In Rus]

3. K Ruys, and D.Stapel, Psychological Science, 19, (April, 2008) [In Rus]

4. V. V.Rubtsov, and I. A. Baeva, Bezopasnost' obrazovatel'noy sredy (Ekon-Inform, Moskva, 2008) [In Rus]

5. V. A.Goryanina, Psihologiya obshcheniya (Akademiya, Moskva, 2002) [In Rus]

6. Entsiklopedicheskiy slovar' po psihologii i pedagogike (2013) [In Rus]

7. T.N. Berezina, Vestnik MGOU,seriya «Psihologicheskie nauki», 3, 16 (2013) [In Rus]

8. Ya.L. Kolominskiy, Psihologiya lichnyh vzaimootnosheniy $v$ detskom kollektive (Narodnaya Asveta, Minsk, 1969) [In Rus]

9. N.N. Kiselev, Sibirskiy pedagogicheskiy zhurnal, 1, 190 (2013) [In Rus]

10. T.V. Chaplya, Sibirskiy pedagogicheskiy zhurnal, 1, 132 (2013) [In Rus] 